\title{
Youth Subcultures ad Social Pedagogy
}

\author{
KEY WORDS \\ youth subcultures, \\ lifestyle, \\ social pedagogy, \\ social pathology, \\ leisureyouth, \\ personal goods
}

\begin{abstract}
Smolík Josef, Youth Subcultures and Social Pedagogy [Subkultury młodzieżowe i pedagogika społeczna]. Kultura - Społeczeństwo - Edukacja nr 2 (4) 2013, Poznań 2013, pp. 65-81, Adam Mickiewicz University Press. ISBN 978-83-232-2708-3. ISSN 2300-0422

This text deals with youth subcultures from the point of view of social pedagogy. Text introduces the basic terms such as culture, the dominant culture, subculture and counterculture and alternative culture. Furthermore there is analyzed the concept of subculture youth as well as the concept of lifestyle. A difference between modern and postmodern approach to subcultures is also mentioned. Furthermore there is described the relationship between youth subcultures and social pedagogy, which is one of the disciplines that are devoted to youth subcultures. The final part of the text briefly discusses selected youth subcultures in the Czech Republic and the negative manifestation of these subcultures.
\end{abstract}

\section{Introduction}

In the 1990s the situation in European society changed fundamentally, and this was reflected in the ways children and young people spend their leisure time. The old geopolitical bipolarity ended, and European integration intensified, though the process was much more complex than originally expected (Pávková et al., 1999). One evident fact of the modern era was a revolutionary transformation in people's ways of thinking about the separate worlds of work and leisure time.

Social pedagogy continues to play its role in shaping mature, complex, multisided individuals seeking the sense of their own lives not only in practical matters, but in satisfying their own private desires and needs through their independent free time (Vážanský, Smékal, 1995). For a significant segment of Central European youth, the main avenue for seeking the meaning of one's own life is the so-called youth subculture. Adolescents in particular often try to realize themselves within the framework of subcultures, which can be seen both as positive 
(making new friends, relationships, hobbies, etc.) or negative (drug dependence, aggression, youth crime, etc.).

Many social pedagogues, social workers, psychologists and sociologists have frequent interaction with the followers of individual youth cultures, individual musical styles and life styles, typified for example by provocative dress, slang, makeup, and behavior. This article will describe in some detail the various youth subcultures (especially in the Czech Republic) and the role of social pedagogy in these areas. The basic terminology will be presented, as well as some of the elements of risk involved with these youth subcultures. Youth subcultures are a fast-evolving topic, as yet insufficiently researched in the post-communist countries; therefore this article can serve as an introduction. At the same time the topic can also be seen as interdisciplinary. The topic of youth subcultures can be examined through a number of social disciplines, for example history, sociology, cultural studies, psychology, political science, social work, and social pedagogy (Džambazovič, 1999; Smolík, 2010). Knowledge about youth culture is indispensable for current social pedagogy, which deals with clients from youth in low-threshold clubs, leisure time centers, or in the context of so-called street work. Some social pedagogues approach this field mainly as the sociology of deviant behavior (Procházka, 2012). Some Czech pedagogues argue that one of the main goals of social pedagogy should be to eliminate the influence of criminogenic youth groups and subcultures (Průcha, 2000; Procházka 2012). For this reason, too, it is worth discussing to what degree membership in youth cultures, as a specific social environment, influences individuals' positive and negative tendencies. Likewise it is worthwhile to become acquainted with the so-called traditional youth subcultures, as this may assist in coming up with possible preventive measures, and improving relations and establishing trust between social pedagogues and the members of youth subcultures.

\section{Basic terminology}

When studying subcultures it is necessary to define the basic terms. Among these terms are culture, dominant culture, subculture, counterculture, and alternative culture. Culture can be defined as the specific way of life of a certain defined group or society of people. This is given by the behavior patterns of the members of that society; that is, the obvious models of behavior and action that an outsider can observe. These behavior patterns lead to a set of expectations and convictions that in turn shape other behavioral patterns. Both activities - the mental and external behavioral - can be regarded as the culture. Although we see culture as a reality, we recognize it only as it is expressed in behavioral patterns (Lawless, 1996). A person becomes a whole individual through the process of learning the culture; in other 
works, adopting as one's own the common personal models of reality. Sociologists refer to this process as socialization (Nakonečný, 1999).

Culture is an integrated and internally-interconnected set or series of ideas, actions, and behavioral patterns that are constantly interacting, the aggregate of the material and spiritual values created and shaped by humanity, representing a certain level of achievement in the history of a society. The individual elements of a culture are configured in unique patterns, forming internally-integrated, relatively autonomous systems, or the models by which the differences among individual cultures are identified. Culture has the following characteristics: it is learned, shared, symbolic, integrated, rational, changing, and adaptive (Lawless, 1996). Průcha, Walterová and Mareš (2001) point out that the term culture has different meanings in the individual social sciences. In the field of pedagogy it is used mainly with the following meanings: 1) Culture as a complex of material, but mainly nonmaterial products (knowledge, ideas, values, moral norms, etc.), which human civilization has developed over time. 2) Culture in the sociological and culturalanthropological sense as the patterns of behavior, shared norms, values, traditions, rituals, etc. that are characteristic of certain social or ethnic groups.

We use the term dominant culture to refer to the most widespread culture within a certain time and space. Today this usually means the majority culture among the middle classes. Within it the existing level of culture and civilization is unquestioned, and there is a conscious effort to tie into the so-called best cultural tradition of the past (Mistrík, 1999: 4).

Subculture is a term that on a general level refers to any (specific) culture that is part of the broader institution of a culture, with which it has some shared and some divergent elements (Geist, 1992; also Hartl, Hartlová, 2000; Giddens, 1999). The degree of divergence of the subculture from the main culture of which it is a part, can be variable; it may diverge only minimally, or it may be in complete opposition to the entire culture (a so-called counterculture). The extent and character of the divergences consist in a number of factors, such as age (so-called youth culture), profession or preparation for such; religion (sects, rituals), origin, nationality, ethnicity, race, social position, social stratum, interests, social institutions, segregation, etc. Where the subculture diverges significantly (especially those that can be characterized as antithetical to the entire culture) there arise tensions and conflicts, which can often lead to dramatic situations. In recent times, subcultures in individual social macro-units have been given heightened attention, and not only by sociology, within which it is beginning to coalesce as an independent discipline, the sociology of subcultures (Hebdige, 1979, 2012). Subcultures sometimes tend towards conscious exclusivity, the creation of so-called group subcultural boundaries, which serve the function of self-maintenance and self-protection. The formation of subcultural boundaries is characteristic of some youth subcultures. 
A subculture is a characteristic set of specific norms, values, behavior patterns, and lifestyles that define a certain group within the context of the broader society. The term subculture relates to a specific group that is the creator and bearer of its own special, differing norms, values, patterns of behavior, and lifestyles, even as it plays a part in the functioning of the broader society. In every case the important indicator of a subculture is its visible difference from the dominant culture. Subcultures do not emerge only in small, isolated pre-industrial societies. Krech, Crutchfield and Ballachey (1968) define subculture as that part of the overall culture of a society that is typical for a certain segment of that society. The prefix „sub-" indicates its distinction and difference from the dominant or mainstream society. Subcultures, then, are composed of groups of people who share their own values and norms by which they set themselves apart from the dominant or mainstream society, and who offer maps of meanings by which the world is made understandable to the subculture's members (Barker, 2006; Kraus, 2008). Bell (1999) describes subcultures as relatively "coherent cultural systems" which, within in the overall system of our national culture, present a world unto themselves. Such systems develop structural and functional peculiarities that distinguish their members to a certain extent from the rest of society (Freiová, 1967; Ondrejkovič, 1998).

The term counterculture indicates that the given culture has turned against the dominant culture. Another term is alternative culture. Implicit in this term is the turning against something; it is an alternative to something. We can also see in this term a creative or enriching element. Even so, there is a clear relationship to another, usually dominant culture (Mistrík, 1999: 4). A counterculture defines and expresses itself in opposition to the main ruling culture in a way that distinguishes it from a subculture. The term is applied especially to the cultural and political movements and formations of the 1960s and 70s in the United States and Great Britain, where the concept first surfaced (Barker, 2006: 92-93).

Línek (1997) states that the countercultures arise especially when there is severe deprivation and frustration, turning against a socio-cultural system regarded as the enemy. Countercultures usually emerge on the edges of society; that is, in socially declassé environments. Motives often given for their appearance are the need to protest, desire for change, and imposing their own (differing) values (Duffková, Urban, Dubský, 2008).

Another term is alternative culture. Alternative is usually understood as an option to choose between two or more ways of approaching things (usually opposed to one another) (Duffková, Urban, Dubský, 2008: 120). An alternative culture thus differentiates itself from the mainstream, popular, or dominant culture.

The concept of the oppositional nature of an alternative lifestyle is quite often applied in the context of the lifestyles of various subcultures that turn more or less explicitly and deliberately against the lifestyle regarded by society as positive and 
worthy of reward, or at least against the lifestyle actually predominant in society, which can be labeled the conventional lifestyle, or pejoratively the conformist lifestyle (Duffková, Urban, Dubský, 2008: 120).

Subcultures (not only youth) are often associated with alternative culture. One of the types of subculture are the youth subcultures, associated in many cases with individual music styles.

\section{Youth subcultures}

The flourishing of youth culture and subsequently youth subcultures became significant especially after the Second World War (Macek, 2003). The work of Mark Abrams (1955) is considered important for the development of subcultural approaches to the young generation in then - Western Europe. Abrams's practically-oriented research on the British market brought interesting findings about the differences in the consumer behavior of young people and their purchasing power. For businessmen this became a signal to develop goods and services for young people. For sociologists, the study brought enough material to define the so-called culture of teenagers, which was understood mainly in relation to free time and consumer goods for free time. Abrams concludes that there are marked differences between young people and older people in the ways free time is spent, but that these differences do not lead to significant conflict behavior. The majority of young people remain anchored to the key institutions - family, school, employment. But the results of Abrams's research on the rise of the first post-war, significantly divergent youth lifestyles (for example the Teddy Boys in Great Britain) were interpreted by some sociologists as proof of the existence of a distinct subculture - a world not subject to the authority, norms, and values of adults (Kabátek, 1989; Abrams, 1959).

Peer groups ${ }^{1}$ based on youth subculture soon came to the forefront of research on the socialization process: individual gangs ${ }^{2}$, parties, or delinquent groups that were active within the generally-defined youth subculture, and that stood out prominently from the dominant (hegemonic, mainstream, majority) culture. Social

${ }^{1}$ The demand to conform is usually higher among peer youth groups than any other group. It includes not only manner of expression, but also external appearance, type of preferred music, behavior towards the opposite sex, attitudes about school or work, parents, money, sexuality, smoking, drugs, alcohol, etc. (Matoušek, Matoušková, 2011: 83).

${ }^{2}$ Gang is the term for a group of young people [seeking to achieve certain goals together, often by illegal means. Especially negative are the violent gangs looking to achieve psychological satisfaction and raise the status of their group through violent actions, and delinquent bands active in crimes against people and property. The term is also used for groups of young people, so-called parties, which are not of anti-social character (Průcha, Walterová, Mareš, 1995: 29; Matoušek, Matoušková, 2011: 84). 
science has been studying so-called youth subcultures intensively since around the mid-1950s (Kabátek, 1989; Thornton, 1997; Macek 2003).

Sociology has been bandying theories about subculture and the very use of the term subculture since the mid-1960s (in French sous-culture de la jeunesse, German Jugendsubkultur, Italian subcultura giovanile, Czech subkultura mladeže) (Col. 1996, Ondrejkovič 1994). Youth subcultures are groups of young (adolescent) people who have something in common (a problem, interest, habit, custom) that distinguishes them from members of other social groups (Thornton, 1997).

One important element in thinking about youth subcultures is the degree of commitment by individuals. In every youth subculture we can identify several types of „insiders”. Besides active members of the individual youth subcultures who for example organize concerts, protests, issue magazines or music media, there is also a broader segment of passive "consumers” who take minimal part in shaping the subculture, but for whom the subculture is very important. A third type of member may be an individual outside the "scene" who follows the fashion trends without caring much about the subculture's ideology (system of norms) and does not work to broadcast the subculture's message (Smolík 2008).

Likewise Androvičová (2007) divides subculture members or so-called scene into three categories: the basic scene $e^{3}$ (people fully engaged in the subculture), factions (members of the subculture who are part of the scene) and the interest scene (a large number of superficial members of the subculture who are not interested in getting deeper into the scene, but often just go along with the style of the subculture). According to Gruber (1997), subcultures serve the following functions in society: 1) they provide a kind of „refuge” for unsocialized individuals, 2) facilitate the communication needed to engage in various interest activities, 3) allow experimentation with new and untried patterns of behavior, 4) display the symptoms of such patterns, and may 5) become the source of significant problems for society (criminality, racial conflict, etc.), or 6) become an expression of the degree of democracy and freedom in society (Gruber, 1997).

Subculture theory, which appeared in the 1950s and 60s, saw the deviant (delinquent) behavior of individual subculture members as a reaction to the culturally-conditioned adaptation problems of certain individuals and groups. This is a collective (not individual) adaptation to structural pressure: deviant or delinquent subcultures represent a protest or defensive reaction against the dominant culture. Subculture theory holds that deviation is the result of conformity of norms and values among those groups of which the individuals are members. The members of certain subcultures often differ little from other members of society. The

3 "Scene” is a commonly-used term related to the topic of subcultures. It is usually used to capture the temporal and spatial influence of individual subcultures. „Scene” is often used to refer to a specific local occurrence of a certain subculture (Ondrejkovič et al., 2009: 78). 
basic difference, however, is in the area of norms - the subculture believes in different rules and different values than those of the conforming majority, and thus they naturally exhibit behavior that from the standpoint of society constitutes deviance (Mühlpachr, 2001).

\section{Subculture and lifestyle}

The term youth subculture is a type of subculture linked to specific behavior by young people, their tendency towards certain value preferences, acceptance or rejection of certain norms, and a lifestyle reflecting their condition. Youth subculture can be meaningfully defined and understood only in comparison with the values and ways of life of adults in that same society. It is usually assumed that youth subculture appears where differences in the life philosophy and life style of young people are historically and situationally emphasized to such an extent that a distinct cultural model of behavior is created (Col., 1996; Thornton 1997).

Today it seems that the stylistic boundaries that separate one youth subculture from another have collapsed. The present period can be characterized as a postsubcultural phase in which young people are the creative bricolage 4 of postmodern consumer society, which entails collecting and selecting various styles and

Table 1. Difference between modern and postmodern (approaches to subculture)

\begin{tabular}{|l|l|}
\hline \multicolumn{1}{|c|}{ MODERN ERA } & \multicolumn{1}{c|}{ POSTMODERN ERA } \\
\hline Clear group identity & Fragmented, dispersed identity \\
\hline Stylistic homogeneity & Stylistic heterogeneity, plurality. \\
\hline Rigid observance of subcultural boundaries & Flexible blurring of subcultural boundaries \\
\hline Subculture is seen as main identity & Many stylistic identities \\
\hline High degree of identification & Low degree of identification \\
\hline Membership seen as permanent & Membership seen as temporary \\
\hline Low degree of subcultural mobility & Temporary affinity for subculture \\
\hline Emphasis on convictions and values & Fascination with style and image \\
\hline Political expression of resistance & Apolitical sensibility \\
\hline Antagonism toward media, lack of trust & Positive perceptions of media \\
\hline Authentic (self-perception) & Awareness of inauthenticity \\
\hline
\end{tabular}

${ }^{4}$ The term bricolage relates to the rearrangement and juxtaposition of originally unconnected elements in such a way as to create a new meaning in a fresh context. Bricolage includes a process of re-signification by which cultural symbols with established meanings are reorganized into new codes of meaning (Barker, 2006: 39; Hebdige, 2012: 158-162). 
mixing them together in a process of blending and comparison. Today's communication technology has created commodities, content, and labels for youth cultures that go beyond the bounds of race or nationality; thus we see global rap, global rave, and global salsa (Barker, 2006: 97-98). Muggleton (2000) notes that in the postmodern era subcultures are merely esthetic codes (the difference between modern and postmodern approach is seen in Table 1.

The fragmentation of youth culture (and subcultures) and the loss of „authenticity" and "style" are such today that we find ourselves in a post-subcultural period, in which style does not mean politicization of youth, but the estheticization of politics (Barker, 2006: 186).

Although it is evident that some subcultures can be labeled as mere "lifestyle" cultures (life-styles) ${ }^{5}$, there still exist subcultures that meet the criteria of the modern era (typical are the skinheads). These subcultures remain wed to a certain ideology through a specific set of values). Although style and ideology are inseparably intertwined, there is also a certain tension between them. This tension springs from the differing emphases placed on these two elements by the individual members of the subculture. Remember that subcultures serve as one of the sources of identity which are outwardly expressed by style, and which are experienced through the acceptable (internalized) ideology. The problem is that various people place different emphasis on these two elements. Especially younger members of the subcultures are more interested in style, while individuals who have been members of the subculture for a longer time tend to put more emphasis on ideology. This conflict has been called the problem of authenticity (Heřmanský, Novotná, 2011: 97-98).

\section{Youth subculture and social pedagogy}

Youth subcultures are certainly no new topic in the social sciences. Although it is relatively difficult to define where the borders are between research and theoretical musing about this problem, in terms of the range of the individual academic disciplines we can say that the topic of youth subculture is very inviting terrain for description and dissection from the standpoint of social pedagogy. Social pedagogy is a transdisciplinary and very integrating discipline. From a practical standpoint it concentrates and further develops the observations of pedagogical, social, and other disciplines (Kraus, 2008: 52).

${ }^{5}$ The term lifestyle can be defined as the set of life models actively pursued by an individual. It includes a person's value orientation, and demonstrates itself in his behavior and his way of using and influencing the circumstances of material and social life. All of these issues can be viewed from the standpoint of free time and the way it is managed. Every person has his own individual system of values, shaped by life conditions and one’s own actions (Pávková et al., 1999). 
The spectrum of interests of social pedagogy is very broad and diverse. Social pedagogy studies pathological social phenomena (issues in contemporary society that have a negative effect or pose a danger to society - for example intolerance, racism, xenophobia, etc.); but which can also positively influence the way young people spend their free time. Social pedagogy can be defined as a borderline academic discipline on the edge between pedagogy, sociology, and psychology. Social pedagogy studies the relationships between the social environment and the socialization of individuals (of various age groups) in their leisure time (Průcha, Walterová, Mareš, 2001; Kraus, 2008).

The aim of social pedagogy is mainly the education of individuals towards responsible fulfillment of his social roles so he becomes a legitimate member of society. Social pedagogy thus deals with how to remove and remedy pathological and other phenomena undesirable for society, remedy them, and incorporate marginalized groups into society (Průcha, Walterová, Mareš, 2001).

Social pedagogy, then, can be defined as pedagogy outside the classroom, the pedagogy of free time, social work with problem groups (gangs, parties). Since some youth cultures are seen and labeled as "pathological”, individual youth subcultures can be seen as target groups for social pedagogy. It is evident that an individual's „entry” into the territory of subcultures (individual gangs), delinquent parties, etc.) can be a motive for subsequent pathological actions and behavior.

Because social pedagogy is close to sociology, the problems of youth subculture we have described can also be seen as a topic that cuts across both disciplines. In the framework of its broader agenda, social pedagogy also deals with youth subcultures, and should target concrete themes, for example socialization ${ }^{6}$ and upbringing of youth, the effects of media, diversity of lifestyles (their norms and expressions), prevention of socially pathological phenomena and risk-prone behavior among peer groups; educational activities aimed at youth, etc. (Kraus, 2004).

A social pedagogue should follow the trends and styles among contemporary youth in a way so as to improve his psychological-counseling, communicative, preventative, and interventional competence. We have in mind especially those social pedagogues who come into contact with youth-based groups (for example members of subcultural gangs) on a regular basis. In many cases one's so-called "subcultural identity" is so important to an individual that it can play an important role during an intervention by a social pedagogue.

${ }^{6}$ Socialization is a lifelong process during which the individual takes on forms of behavior and action, knowledge, language, values, and culture, and becomes incorporated into society. The process of socialization starts with social teaching (teaching that takes place in social environments and situations), social communication and interactions (Procházka, 2012). 
Džambazovič (1999) also points out that a young person in his effort to achieve individuality and originality is confronted with the technologically rationalized and bureaucratized order of institutions: in this confrontation he is anonymous, and vulnerable. He therefore seeks a feeling of collectivity and belonging, which is demonstrated in his search for others who confirm and reflect his individuality.

For reasons of thematic focus, too, social pedagogy should reflect the observations of sociology (sociology of education, youth sociology, or social pathology), social psychology (dynamics, values, and roles within the framework of small social groups, etc.), and on the practical level of social work.

Important from the standpoint of sociology is the issue of the status of young people in the society, or within the youth subcultures. Important from a psychological point of view is the motivation of young people to become part of a youth subculture, and its influence on the psyche of these individuals. From the standpoint of pedagogy what is basic is the meaning of subculture for the formation of the adolescent personality in the process of socialization and upbringing (Jusko, 2007: 252).

The social pedagogue, as we have said above, (like the other professions dealing with young people) should become well acquainted with the issues of youth subcultures, especially in order to understand the behavior of adolescents who move in the specific environments of the individual subcultures.

Czech social pedagogy has partly dealt with the phenomenon of subcultures, as have other social sciences (Kraus, 2008; Kraus, Hroncová et al., 2007). In thinking about youth subcultures, three levels of this phenomenon must be examined: 1) the level of the individual, 2) the level of small social groups (parties, gangs), and 3) the level of the whole society (macro-environment). All these levels should appear in theoretical as well as empirical studies dealing with youth subcultures. Some of the empirical studies done in the Czech Republic have successfully looked at subcultures from the perspective of social pedagogy; this is documented by a number of articles and monographs (Smolík, 2008, 2010; Lojdová, 2011, 2013). Even so, there has not yet been any broader treatment of this issue, especially on the level of the positive elements of youth subcultures. From the standpoint of majority society, the prevailing interest is youth subculture's potential risk factor, and the socio-pathological phenomena and deviations that are frequently displayed by individual subcultural parties and gangs.

\section{Youth subcultures in the $C R$ and their potential risks}

Youth subcultures are defined by individual peer relationships. Peers play an important role in the life of every person. Peer groups (including the parties active in 
the individual subcultures) and their influence on youth can be described through understanding the characteristics of social groups and individual subcultures and in relation to the content, values, and norms at work within these types of groups. A social group or youth subculture through which individuals wish to successfully realize themselves must offer the kind of characteristics that attract the individual, make him want to be part of the group, and satisfy his needs, visions, desires, and relationships (Smolík, 2010; Procházka, 2012).

On the basis of youth subcultures, these peer groups existed in a relatively consistent form even before 1989 (Vaněk, 2002). For example, this period saw the appearance of subcultures such as punk, skinheads, and a relatively developed metal scene.

In general we can say that, in the countries of the so-called East block, youth subcultures (and other subcultures) were a form of escape from formal, authoritarian oversight (Džambazovič, 1999). The subcultures have always been a source of innovation and creative energy; at present the intensity of innovation is increasing, resulting in changes in lifestyle.

Subcultures in Czechoslovakia have been discussed since the 1960s, but the term was rejected by some. Greater interest appeared in the mid-1980s in response to the fact that youth subcultures developed abroad, and were transferred into socialist society in the form of informal groups that did not wish to organize within the communist youth groups (Kolářová, 2011: 33).

In the Central European area, too, trends characteristic of the postmodern era are evident. Since the late 1990s the region has been one great "mix" of subcultures that can be characterized as the "postmodern youth style" (Thornton, 1995; Džambazovič, 1999; Smolík, 2010).

It is very difficult to determine how many youth subcultures are currently present in the Czech Republic; even so, we can identify a few youth subcultures with enough members, sufficiently ideologically profiled, and acknowledged over time to be identified as youth culture. It is estimated that only one in twenty young people will identify with some youth subculture. Among Czech adolescents the skinheads have the largest number of followers (in all the sub-currents), followed by metal (with many subgenres), punk and hardcore, graffiti, football hooligans, hippies, and a broadly-defined, many-thousand-member dance scene in the styles of house, trance, psytrance, drum 'n'bass, techno, techno, free-techno, and others (Smolík, 2005). In recent years styles such as emo and gothic rock have also made inroads among young people.

All the above subcultures are often associated with risk-prone behavior or socio-pathological activity. Some social pedagogues or sociologists speak openly of so-called at-risk youth. 
At-risk youth (problem young people, threatened young people) are those groups of young people who, under a mix of biological, psychological, and cultural mix of conditions, are prone to behavior that threatens their long-term psychological and social development as they mature; and their behavior is seen by their social environment as a danger. Risk-prone behavior by young people is associated with a stage of psycho-social development that combines the search for identity with biological, psychological, social, and professional maturing. Risk-prone behavior is also conditioned on the culmination of social roles and social influences in unfavorable family, partnership, and other social situations (Kasal, 2013: 347). The term at-risk youth is debatable because it can be interpreted in different ways. Even so some authors argue that this term: 1) is broad enough to cover this circle of social problems with youth, but is still open enough to other types of undesirable behavior; 2) it is deep enough to contain the entire process, from the first minor indicators, to serious problems of the individual or small social group (Labáth et al., 2001: 12). The actions of this segment of youth are associated with so-called risk-prone behavior. This term refers to behavior patterns that can result in a demonstrable growth in educational, health, social, and other risks, both for individuals and society (Procházka, 2012: 133). Related concepts include delinquent behavior, social pathology ${ }^{7}$, and social deviation (Mühlpachr, 2001; Ondrejkovič et al., 2009) ${ }^{8}$.

Subcultures, or individual subculture-related parties, can also have an influence on deviant or delinquent behavior. The individual in such a case may engage in deviant behavior because the subculture provides him with 1) the necessary support (for example ideological justification); 2) organization and coordination

${ }^{7}$ A socio-pathological phenomenon generally means individual behavior such as unhealthy lifestyle, ignoring or violating social norms, law, and ethical values; behavior and actions, which leads to damage to the individual and the environment in which he lives and works, and thus to individual, group, and social disruption and deformation (Pokorný, Telcová, Tomko, 2002: 4) Social pathology is a catch-all term for undesirable social phenomena which are dangerous, unhealthy, and abnormal, and are regarded by society as negatively-sanctioned forms of deviant behavior (Mühlpachr, 2001).

${ }^{8}$ The term social deviation includes various behaviors, phenomena that disturb us and distress us (Mühlpachr, 2001). Social deviation is any kind of divergence in behavior from social norms, which at the same time violate the formal or informal requirements placed on human behavior in the given society (Mühlpachr, 2001; Munková 2001). Social deviation is thus a broader term than social pathology; it is semantically and emotionally neutral in the sense that it does not say which behavior is „bad" and which is "good”. This points to the need to judge behavior within the context of the culture and subculture, the changing nature of the environment, and the influence of life situations experienced by concrete people in a concrete space and time (Procházka, 2012: 125)

Deviation has a universal character; meaning that it exists in all societies, everywhere where people come into contact with one another and live in groups. There is no such thing as a society or culture in which its members display an entirely conformist behavior with the complete absence of deviation (Mühlpachr, 2009: 43). 
of deviant activities (violent demonstrations); 3 ) structure for free-time activities; 4) a structure for division of labor; 5) a role within the subculture of the party; and 6) protection against the agents of social control (law-enforcement, courts, etc.). This protection can take the form of legal assistance, financial support, solidarity, etc.

The list of social deviations and socially pathological phenomena that are often connected to youth subculture includes: 1 . Criminality (particularly petty theft and delinquency, 2. Alcoholism, 3. Smoking (tobacco), 4. Drug dependence (abuse of narcotic and hallucinogenic substances), 5. Sexual promiscuity (typical in the past for example of the hippies subculture), 6. Political orthodoxy (racism, political radicalism, anti-Semitism, political violence, intolerance), 6. Suicide (typical for emo/gothic rock), 7. Vandalism, 8. Aggression, 9. self-damaging (typical for emo/gothic rock), etc. (Smolík, 2008).

Even though it is evident that some followers of certain youth subcultures engage in these negative social phenomena, it must be pointed out that youth subcultures or their individual styles (that is, natural forms of youth association) cannot be regarded a priori as criminal.

\section{Conclusion}

Social pedagogy, as a relatively new field but with a long history, struggles with an unclear definition and focus of its studies. Because of the many approaches to the study of social pedagogy and the topics that social pedagogy touches on - free time, out-of-school upbringing, etc. - we can say that interest in social pedagogy and youth subcultures is legitimate and desirable. We can also say that the fact that in the Czech environment some of the monographs and academic papers on subcultures or on individual youth lifestyles are being produced; at the level of practice, contact with members of youth subcultures is also evident at the level of street work (Bednářová, Pelech, 1999; Matoušek, Matoušková, 2011).

The knowledge of individual subcultures can improve an individual teacher's relationships with students, mitigate possible bias in relations to students, and contribute to a better reception of the pedagogue by the students who are members of the individual subcultures.

Therefore, in this conclusion we would point out the lack of systematic preventive work with members of the individual subcultures. From the sociological, psychological, and pedagogical standpoint it will be necessary to study what free time activities within the framework of the subcultures contribute to the formation of interpersonal relations, whether they help or hinder the cultivation of such 
relations, etc.] (Pávková et al., 1999). Theoretical considerations should be supported with serious research on these topics. We must look at youth subcultures as a reflection of society, a mirror we hold up to ourselves, which warns us against indulging too much in some of our dogmas. Today's subcultures can be regarded as vehicles for escaping the uniformity of the globalized world (Hermanský, Novotná, 2011). Or contemporary subcultures can be seen as islands which, as a consequence of the mass media, music, and clothing industries, are rapidly shrinking and losing their authenticity. This, too, is a phenomenon that social pedagogy should take note of.

\section{Literatura}

Abrams M. (1959). The Teenager Consumer. London

Androvičová J. (2007). Deviantné subkultúry mládeže a rasistický a pravicový extremizmus. (W:) Radikalismus v současném světě. Sborník z mezinárodni vědecké konference, 10-11 5. 2007 $v$ Kolině. Red. V. Srb, P. Hirtlová. Kolín, s. 14-21

Barker Ch. (2006). Slovník kulturálních studií. Praha

Bednářová Z., Pelech L. (1999). Sociální práce na ulici: streetwork. Brno

Bell D. (1999). Kulturní rozpory kapitalismu. Praha

Duffková J., Urban L. Dubský J. (2008). Sociologie životního stylu. Plzeň

Džambazovič R. (1999). Nové možnosti interpretácie mládežníckej subkultúry. (W:) Súčasné subkultúry mládeže. Zborník príspevkov ze seminára Sekce sociologickém teorie Slovenskej sociologickém společnosti při SAV uskutečněného 21. októbra 1998. Red. R. Džambazovič, R. Klobucký. Bratislava

Freiová A. (1967). Překlady prací západoevropských sociologů k problematice sociologie mládeže. Praha

Geist B. (1992). Sociologický slovník. Praha

Giddens A. (1999). Sociologie. Praha

Gruber J. (1997). Význam subkultur. „Éthum: Bulletin pro Sociální Prevenci a Sociální Pedagogiku" 15, s. 12-15

Hartl P., Hartlová H. (2000). Psychologický slovník. Praha

Hebdige D. (1979). Subculture: The Meaning of Style. London

Hebdige D. (2012). Subkultura a styl. Praha

Heřmanský M., Novotná H. (2011). Hudební subkultury. (W:) Folklor atomového věku. Kolektivně sdílené prvky expresivní kultury v soudobé české společnosti. Red. P. Janeček. Praha

Jusko P. (2007). Rizikové subkultúry súčasnej mládeže. (W:) Sociální patologie. Red. B. Kraus, J. Hroncová a kol. Hradec Králové

Kabátek A. (1989). Mládež - generace - kultura. „Sociologický Časopis” č. 5, s. 449-467

Kasal J. (2013). Riziková mládež. (W:) Encyklopedie sociální práce. Red. O. Matoušek a kol. Praha, s. $347-350$

Kolářová M. (2011). Úvodem: zkoumání subkultur od stolu i v terénu. (W:) Revolta stylem. Hudební subkultury mládeže v České republice. Red. M. Kolářová. Praha, s. 13-43 
Kraus B. (2004). Kaktuálnímu pojetí sociální pedagogiky. (W:) Konstituování sociální pedagogiky jako vědeckého oboru. Brno, s. 9-19

Kraus B. (2008). Základy sociální pedagogiky. Praha

Kraus B., Hroncová J. a kol. (2007). Sociální patologie. Hradec Králové

Krech D., Crutchfield R., Ballachey E.L. (1968). Člověk v spoločnosti. Bratislava

Labáth V. a kol. (2001). Riziková mládež. Praha

Lawless R. (1996). Co je to kultura. Olomouc

Lojdová K. (2011). Hodnoty v prostředí punkové subkultury. „Studia Paedagogica” roč. 16, č. 2, s. $131-157$

Lojdová K. (2013): Subkultury ve veřejné pedagogice. Brno

Macek P. (2003). Adolescence. Praha

Matoušek O., Matošková A. (2011). Mládež a delikvence: možné příčiny, struktura, programy prevence kriminality. Praha

Mistrík E. (1999). Dominanta a alternatíva. (W:) Súčasné subkultúry mládeže. Zborník príspevkov ze seminára Sekce sociologickém teorie Slovenskej sociologickém společnosti přri SAV uskutečněného 21. októbra 1998. Red. R. Džambazovič, R. Klobucký. Bratislava, s. 4-7

Muggleton D. (2000). Inside Subculture: The Postmodern Meaning of Style. Oxford

Mühlpachr P. (2001). Sociální patologie. Brno

Mühlpachr P. (2009). Sociopatologie. Brno

Munková G. (2011). Sociální deviace (přehled sociologických teorií). Praha

Nakonečný M. (1999). Sociální psychologie. Praha

Ondrejkovič P. (1994). Štúdie zo sociologie výchovy. Teoretické základy sociologie výchovy a mládeže. Bratislava

Ondrejkovič P. (1998). Úvod do sociologie výchovy. Bratislava

Ondrejkovič P. a kol. (2009). Sociálna patológia. Bratislava

Pávková J. a kol. (1999). Pedagogika volného času. Teorie, praxe a perspektivy mimoškolní výchovy a zařizení volného času. Praha

Pokorný V., Telcová J., Tomko A. (2002). Patologické závislosti. Brno

Procházka M. (2012). Sociální pedagogika. Praha

Průcha J. (2000). Přehled pedagogiky: úvod do studia oboru. Praha

Průcha J. Walterová E., Mareš J. (2001). Pedagogický slovní. Praha

Smolík J. (2005). Subkultury mládeže v České republice. Brno

Smolík J. (2008). Subkultury mládeže a sociálně patologické jevy. (W:) K. Večerka. Trendy sociálně patologických jevio. Sborník príspěvkư ze semináře sekce sociální patologie MČSS. Praha, s. 101-108

Smolík, J. (2010). Subkultury mládeže. Uvedení do problematiky. Praha

Thornton S. (1997): General Introduction. (W:) K. Gelder, S. Thornton. The Subcultures Reader. London, s. 1-11

Vaněk M. (2002). Kytky v popelnici. Punk a nová vlna v Československu. (W:) M. Vaněk a kol.. Ostrůvky svobody. Kulturní a občanské aktivity mladé generace v 80. letech v Československu. Praha, s. 175-235

Vážanský M., Smékal, V. (1995). Základy pedagogika volného času. Brno

Velký sociologická slovník. (1996). Praha 


\title{
Subkultury młodzieżowe i pedagogika społeczna
}

\author{
Streszczenie
}

Artykuł dotyczy problematyki subkultur młodzieży z punktu widzenia pedagogiki społecznej (resocjalizacyjnej). Dla istotnego segmentu młodzieży środkowoeuropejskiej środowisko tak zwanych młodzieżowych subkultur stanowi zupełnie naturalny składnik socjalizacji. Duża część pedagogów społecznych (resocjalizacyjnych), pracowników socjalnych, psychologów i socjologów spotyka się z osobami identyfikującymi się z poszczególnymi subkulturami młodzieżowymi, z różnymi gatunkami muzycznymi lub stylami życia, wyróżniającymi się na przykład prowokacyjnym ubiorem, używaniem specyficznego slangu, makijażem lub zachowaniem.

Autor artykułu opisuje subkultury młodzieżowe i rolę pedagogiki społecznej (resocjalizacyjnej) w danej dziedzinie; prezentuje szczegółowo również podstawową terminologię (kultura, kultura dominująca, subkultura, subkultura młodzieżowa, styl) oraz odnosi się do elementów ryzyka, które towarzyszą środowiskom subkultur młodzieżowych.

Rozwój kultury młodzieżowej i następnie subkultur młodzieżowych nasilił się zwłaszcza po II wojnie światowej. Subkultury młodzieżowe stawały się stopniowo czołowym tematem badań procesów socjalizacji. W artykule zaprezentowano „kryterium zaangażowania jednostki” w subkulturę młodzieżową („aktywni zwolennicy” - „insiderzy” - „konsumenci”). W dyskusji, która się toczy wśród badaczy, dominuje teza, że obecnie mamy do czynienia z tak zwaną fazą postsubkluturową, co oznacza, że nie ma jasnych linii rozgraniczajacych style poszczególnych subkultur. Można sie zgodzić z wnioskami Muggletona (2000), że w ponowoczesności subkultury stanowią wyłącznie kody estetyczne. Przejawem tego jest rozproszenie subkultur młodzieżowych, które utraciły dawną autentyczność. Choć jest ewidentne, że część z nich można utożsamić wyłącznie ze stylem życia, w dalszym ciągu istnieją również subkultury, które spełniają kryteria ery nowoczesności (np. skinheads), są bowiem one w dalszym ciągu związane z określoną ideologią (ze zbiorem specyficznych wartości).

Ze względu na to, że niektóre subkultury młodzieżowe są określane i postrzegane jako „patologiczne”, można je także traktować jako grupę docelową dla interwencji pedagogiki społecznej (resocjalizacyjnej). Jest ewidentne, że „wejście” jednostki na terytorium subkultur (poszczególnych gangów, grup osób niedostosowanych itp.) może być impulsem do aktów i zachowań patologicznych.

Pedagodzy powinni śledzić trendy i style życia współczesnej młodzieży w taki sposób, by podnosić swoje kompetencje psychologiczne, doradcze, kompetencje w zakresie komunikacji, profilaktyki i interwencji. Tak zwana „tożsamość subkulturowa” w wielu przypadkach jest dla jednostki na tyle ważna, że może odgrywać istotną rolę, zwłaszcza podczas interwencji pedagogicznej.

W artykule zaprezentowano także w sposób skrótowy wyniki badań czeskich pedagogów, socjologów oraz przedstawicieli specjalności praca socjalna. Według szacunków w Republice Czeskiej z określoną subkulturą młodzieżową utożsamia się co dwudziesty młody człowiek. Do najczęściej wybieranych należą subkultury: skinheadów, metalowców, punk i hardcore, graffiti, kibiców piłkarskich, hippisów i szeroko pojmowana wielotysięczna scena taneczna stylów takich jak house, trance, psytrance, drum 'n'bass, techno, tekkno, freetekno itp.

Spośród dewiacji społecznych i zjawisk patologicznych, które często wiążą się z subkulturami młodzieżowymi, należy wymienić następujące: 1) przestępczość (zwykle drobne kradzieże) i wykroczenia, 2) alkoholizm, 3) palenie papierosów 4) uzależnienie od narkotyków (psycho- 
tropy i opiaty), 5) rozwiązłość seksualną (w przeszłości charakterystyczną dla subkultury hippisów), 6) ortodoksję (rasizm, radykalizm polityczny, antysemityzm, nietolerancję), 7) skłonności samobójcze (typowe dla emo/gothic rock), 8) wandalizm, 9) agresję, 10) samouszkodzenia (typowe dla emo/gothic rock) itp.

Wiedza na temat wyżej prezentowanych subkultur może poprawić relacje pomiędzy nauczycielami/wychowawcami i uczniami/studentami, którzy przynależą do środowisk subkulturowych. 